\title{
Ozone Pollution Alters Olfaction and Behavior of Pollinators
}

\author{
Maryse Vanderplanck 1,2,*(D), Benoît Lapeyre ${ }^{3}$, Margot Brondani ${ }^{3}$, Manon Opsommer ${ }^{3}$, Mathilde Dufay ${ }^{3}$, \\ Martine Hossaert-McKey ${ }^{3,4}$ and Magali Proffit ${ }^{3}$
}

1 UMR 8198-Evo-Eco-Paleo, Université de Lille, CNRS, 59000 Lille, France

2 Laboratoire de Zoologie, Université de Mons, 7000 Mons, Belgium

3 Centre d'Écologie Fonctionnelle et Évolutive (CEFE), Université de Montpellier, CNRS, EPHE, IRD, 34293 Montpellier, France; benoit.lapeyre@cefe.cnrs.fr (B.L.); brondani.margot@gmail.com (M.B.); opsommer.m@gmail.com (M.O.); mathilde.dufay@cefe.cnrs.fr (M.D.); martine.hossaert@cefe.cnrs.fr (M.H.-M.); magali.proffit@cefe.cnrs.fr (M.P.)

4 Laboratoire de Chimie Bio-Inspirée et Innovations Écologiques (CHIMECO), CNRS, Université de Montpellier, 34790 Grabels, France

* Correspondence: maryse.vanderplanck@umons.ac.be; Tel.: +32-65-37-38-93

Citation: Vanderplanck, M.; Lapeyre, B.; Brondani, M.; Opsommer, M.; Dufay, M.; Hossaert-McKey, M.; Proffit, M. Ozone Pollution Alters Olfaction and Behavior of Pollinators. Antioxidants 2021, 10, 636. https:// doi.org/10.3390/antiox10050636

Academic Editor: Hiroko Tabunoki

Received: 24 March 2021

Accepted: 16 April 2021

Published: 21 April 2021

Publisher's Note: MDPI stays neutral with regard to jurisdictional claims in published maps and institutional affiliations.

Copyright: (c) 2021 by the authors. Licensee MDPI, Basel, Switzerland. This article is an open access article distributed under the terms and conditions of the Creative Commons Attribution (CC BY) license (https:// creativecommons.org/licenses/by/ $4.0 /)$.

\begin{abstract}
Concentration of air pollutants, particularly ozone $\left(\mathrm{O}_{3}\right)$, has dramatically increased since pre-industrial times in the troposphere. Due to the strong oxidative potential of $\mathrm{O}_{3}$, negative effects on both emission and lifetime in the atmosphere of plant volatile organic compounds (VOCs) have already been highlighted. VOCs alteration by $\mathrm{O}_{3}$ may potentially affect the attraction of pollinators that rely on these chemical signals. Surprisingly, direct effects of $\mathrm{O}_{3}$ on the olfaction and the behavioral response of pollinators have not been investigated so far. We developed a comprehensive experiment under controlled conditions to assess $\mathrm{O}_{3}$ physiological and behavioral effects on two pollinator species, differing in their ecological traits. Using several realistic concentrations of $\mathrm{O}_{3}$ and various exposure times, we investigated the odor antennal detection and the attraction to VOCs present in the floral scents of their associated plants. Our results showed, in both species, a clear effect of exposure to high $\mathrm{O}_{3}$ concentrations on the ability to detect and react to the floral VOCs. These effects depend on the VOC tested and its concentration, and the $\mathrm{O}_{3}$ exposure (concentration and duration) on the pollinator species. Pollination systems may, therefore, be impaired in different ways by increased levels of $\mathrm{O}_{3}$, the effects of which will likely depend on whether the exposure is chronic or, as in this study, punctual, likely causing some pollination systems to be more vulnerable than others. While several studies have already shown the negative impact of $\mathrm{O}_{3}$ on VOCs emission and lifetime in the atmosphere, this study reveals, for the first time, that this impact alters the pollinator detection and behavior. These findings highlight the urgent need to consider air pollution when evaluating threats to pollinators.
\end{abstract}

Keywords: ozone; atmospheric pollution; plant-pollinator interactions; pollinators; plant VOC perception; behavioral response

\section{Introduction}

It is widely recognized that global change due to human activities has already had major impacts on the biodiversity and on biotic interactions, including pollination, and that these impacts will be increasingly severe [1-3]. Insect pollination is a key component of biodiversity, providing a fundamental ecosystem service in natural and agricultural ecosystems [4-6]. A series of major threats to insect pollination have been identified and new political lines of action have been proposed $[3,6]$. Surprisingly, among these identified threats to pollination and its associated organisms, air pollution has received limited attention $[7,8]$. However, the concentrations of major air pollutants in the atmosphere have tremendously increased since pre-industrial times, and are predicted to further increase in some areas of the world [9]. Among widespread atmospheric pollutants, the tropospheric ozone $\left(\mathrm{O}_{3}\right)$ is one of the most harmful air pollutants to ecosystems, especially in rural 
areas $[2,9,10]$. Ozone concentrations fluctuate in space and time [10], reaching particularly high in areas combining important human activities and a warm climate [11,12]. On a worldwide scale, baseline $\mathrm{O}_{3}$ concentration has doubled since the pre-industrial period and is likely to increase by $2-4$ folds in the next two decades, mainly due to global warming and changes in land cover $[9,10,13]$. Depending on climatic conditions, $\mathrm{O}_{3}$ concentration presents local seasonal peaks, called $\mathrm{O}_{3}$ episodes, which result in high $\mathrm{O}_{3}$ concentrations ( $>40 \mathrm{ppb}$ ) during short time periods. Predictive models show an increased frequency of high $\mathrm{O}_{3}$ episodes by 2050 in some areas of the world [14]. These $\mathrm{O}_{3}$ episodes can have detrimental effects not only on human health (e.g., respiratory health problems, cognitive dysfunction) [15-18], but also on vegetation (e.g., plant damages, productivity losses) $[19,20]$. However, $\mathrm{O}_{3}$ effects on biotic interactions are still poorly documented even though these interactions are essential for ecosystem functioning and services. There is especially an urgent need to characterize the direct impact of such $\mathrm{O}_{3}$ episodes on plant-pollinator interactions, especially from the pollinator perspective [21].

Investigating the effect of $\mathrm{O}_{3}$ episodes on pollinators requires taking into account the existing interspecific variation in terms of species ecological traits, which are known to be related to the sensitivity to environmental disturbances [22,23]. Size, dietary specialization, and degree of sociality of species may determine the extent to which abiotic and biotic conditions affect their survival and resource use. Such differential sensitivity of insects has been already investigated and highlighted in the context of pesticide use, land use, and land cover change [24-27]. One might then expect that resistance of pollinators to oxidative stress, as caused by $\mathrm{O}_{3}$ exposure (i.e., direct effects and physiological tolerance), which may vary among species according to their ecological traits. For instance, longevity is associated with increased resistance to oxidative stress in some insect species [28,29]. Food intake is also associated with resistance to oxidative stress, with an access to dietary antioxidants, making organisms more prone to resist oxidative stress than others (i.e., nonfeeding organisms or absence of antioxidants in the normal diet) [30]. All these pollinator ecological traits also mediate their interactions with plants, and are complementary to underpin the stability, structure, and complexity of pollination networks.

One crucial aspect of plant pollination by insects is how efficiently the interacting partners encounter one another. A large majority of plant-pollinator interactions are mediated by chemical communication. This type of communication may be basically summarized by the following steps: the emission of volatile organic compounds (VOCs) by flowers, which are further diffused in the ambient air, and ultimately detected and used by pollinators as a signal to locate their host-plant [31-33]. Several studies have pointed out that air pollution can potentially affect all levels of this chemical communication [21,34-38]. Ozone, due to its strong oxidative potential, has actually been shown to affect the emission rates and profiles of plant VOCs [2,37,39-41], as well as their lifetime in the atmosphere [37,42-44]. Consequently, the alteration of the floral scent chemical composition either at the emission or during their transport in the air may reduce insect success rates in locating plumes of floral scents [44]. However, research on whether the effects of $\mathrm{O}_{3}$ on pollinator behavior and their capacity to locate their host flowers has been neglected until now [21].

Within the complex mixtures of VOCs emitted by plants, insects only use some of them, in particular proportions, as a signal to find their resource $[31,45,46]$. Any change in the detection of the different VOCs in a floral scent by insects can lead to the breakdown of the host recognition process and may, thus, impede pollinator foraging. In insects, the antenna is the primary organ involved in the detection of VOCs [47]. This elaborate organ hosts most of the olfactory sensory neurons (OSNs) where the chemosensory proteins implicated in VOCs detection are expressed. When OSNs membrane proteins recognize VOCs, they will trigger neurons to send electrical signals to the insect brain that will then process these sensory inputs to produce a behavioral response according to the chemical signal received [47-49]. It is likely that a powerful oxidant like $\mathrm{O}_{3}$ may react with the antennal chemosensory proteins [16], potentially hindering VOCs detection by the individual. So far, only one study has shown that an increased level of $\mathrm{O}_{3}$ differently affects 
antennal responses in western honeybees (Apis mellifera) depending on the VOC tested [50]. Unfortunately, the experimental design used does not allow for distinguishing the effects of $\mathrm{O}_{3}$ on VOCs themselves from the direct effect on insect antennal detection. Direct evidence for $\mathrm{O}_{3}$ effects on the VOCs detection and the behavioral response of pollinators are, therefore, still missing to have a complete picture of the $\mathrm{O}_{3}$ threat to pollination [21].

The objective of this study was to investigate the impact of $\mathrm{O}_{3}$ episodes on both: (i) the ability of pollinators to detect VOCs from their associated plant species, and (ii) on the subsequent behavioral response to host-plant VOCs, by using two pollinator species differing in their ecological traits to control for species dependence. Our working hypotheses were that $\mathrm{O}_{3}$ would induce an alteration of the VOCs antennal detection and a modification of their behavioral response to the stimulus. In order to test our hypotheses, we first exposed individuals to simulated $\mathrm{O}_{3}$ episodes of different intensity and length of exposure that occurred in the Mediterranean region, which is one of the most impacted by $\mathrm{O}_{3}$ pollution in Europe. Then, using synthetic VOCs mimicking floral scents, we tested if the exposure affected: (i) insect antenna sensitivity (by recording the electroantennogram responses to different VOCs doses), and (ii) pollinator attraction to these VOCs.

\section{Materials and Methods}

\subsection{Model Systems}

\subsubsection{Fig Wasp System}

As a model of short-lived species, we used the solitary and tiny fig wasp Blastophaga psenes L. (Hymenoptera, Agaonidae), which lives between one and two days and does not feed at the adult stage [51]. Blastophaga psenes is involved in a highly specific mutualism with the Mediterranean fig species Ficus carica (Moraceae), being intimately associated with this plant for its reproduction and being its exclusive pollinator. Ficus carica occurs naturally in the Mediterranean region and presents an unusual phenology with male trees flowering twice a year (i.e., in late April—early May and in late July), but female trees flowering only once a year (i.e., in early July) (see [46,52] for more details about the life cycle. Blastophaga psenes uses a blend of 4 VOCs [S-linalool, Z-linalool oxide (furanoid), E-linalool oxide (furanoid) and benzyl alcohol] in the proportion of $76.34 \%, 0.38 \%, 0.38 \%$, and $22.90 \%$, respectively, to locate receptive figs of its host and any small change in this blend proportion alters pollinator attraction [46]. All these biological properties of this fig-fig wasp association make it particularly well suited for understanding how specific plant-insect communication may be affected by atmospheric pollution.

This study was carried out with insects from natural populations collected in fig trees present at the CEFE ("Centre d'Ecologie Fonctionnelle et Evolutive") experimental garden $\left(43^{\circ} 38^{\prime} 19^{\prime \prime} \mathrm{N}, 3^{\circ} 51^{\prime} 49^{\prime \prime} \mathrm{E}\right)$ in Montpellier, France. Newly emerging adult female wasps were collected from mature figs taken haphazardly from different individual male trees. Because of their very short lifespan outside the fig, individuals of $B$. psenes were tested shortly after their exit from their natal Figure Each day, a maximum of 25 individuals were tested per treatment. All tested wasps were naïve to the VOCs used in the experiments.

\subsubsection{Bumblebee System}

As a model of long-lived species, we used the buff-tailed bumblebee Bombus terrestris (L.) (Hymenoptera, Apidae), which is one of the most abundant and widespread bumblebee species in the western Palearctic. This social species lives about three weeks $[53,54]$ and is highly polylectic, foraging on hundreds of different plant species belonging to numerous plant families [55-57]. As a consequence, it has a very important role as a pollinator in wild and cultivated plant communities [56,58]. However, colonies do not show equivalent development on all pollen species [59]. Host-plant recognition is then of primary importance. Although bumblebees are especially attracted to plants with blue flowers and radial nectar guides [60], plants VOCs also play an important role in attraction and host discrimination [61]. Actually, the olfactory signal is a primary cue that influences the bumblebee's foraging decision and reduces uncertainty regarding visual cues [62]. The 
sensory abilities of bumblebees and their learning and memory capabilities are well known, which makes them one of the most suitable models for conducting behavioral studies [63].

Commercial colonies of $B$. terrestris are available and easy to rear so that physiological measures can be performed in the laboratory under controlled conditions. For all the experiments, bumblebee foragers were collected from three different colonies of two-dayold workers supplied by Biobest $b v b a$ (Westerlo, Belgium). The tested individuals were not age-marked, but they could be considered to have had similar olfactory experiences because of prior exposure to the same odors inside the colony and because they were not allowed to forage outside the nest. The colonies were fed ad libitum with sugar syrup (BIOGLUC ${ }^{\circledR}$, Biobest) and pollen candies (i.e., Salix pollen provided by Ruchers de Lorraine) in a dark room at $27^{\circ} \mathrm{C}$ and $76 \%$ relative humidity during a 30-day period. New pollen candy was provided every two days. Syrup and pollen supplies were done in the darkroom under red light in order to avoid disturbing colonies, as bees do not detect this range of the light spectrum.

\subsection{Ozone Exposure}

In the Mediterranean region, $\mathrm{O}_{3}$ episodes (>40 ppb) frequently occur during the summertime, and concentrations of around $80 \mathrm{ppb}$ are commonly registered for several hours. However, the maximum hourly concentration was habitually around $120 \mathrm{ppb}$ and exceptionally up to $208 \mathrm{ppb}$ in the last 20 years [64]. As we aimed to simulate realistic $\mathrm{O}_{3}$ episodes of various intensities and lengths, we exposed individuals of each species for a short period (60 min) to $200 \mathrm{ppb}$ (very high concentration) (i.e., highest hourly value that was recorded in the Mediterranean region [64]), and for a longer period (180 $\mathrm{min})$ to $80 \mathrm{ppb}$ (intermediate concentration) or $120 \mathrm{ppb}$ (high concentration) (i.e., average values that may be recorded over several hours every year $[13,65])$. Controls with individuals exposed to $0 \mathrm{ppb}$ for either 60 or $180 \mathrm{~min}$ were also run in parallel. The greater and more prolonged availability of bumblebees, compared to fig wasps, allowed us to conduct additional exposure treatments on this species in order to better cover the effects of $\mathrm{O}_{3}$ on insect olfaction (see Table S1 for details about exposure conditions and sample sizes).

To conduct these exposures, pollinators were placed into a laboratory fumigation chamber held at room temperature $\left(27^{\circ} \mathrm{C}\right)$. Ozone was produced using the photolysis of molecular oxygen subjected to UV radiation at a wavelength of $185 \mathrm{~nm}$ (UV photometric Ozone Analyser with a generator option, Model 49i, Thermo Fisher Scientific ${ }^{\mathrm{TM}}$, Franklin, MA, USA). The fumigation system consisted of a glass bottle of $500 \mathrm{~mL}$ with a filter paper of $2 \times 2 \mathrm{~cm}$ loaded with $200 \mu \mathrm{L}$ of distilled water (fig wasps) or inverted sugar syrup (bumblebees) before the exposure. One side of the glass bottle was connected to the analyzer-generator in the generator mode pushing air containing different concentrations into the bottle at the flow rate of $1.5 \mathrm{~L} \cdot \mathrm{min}^{-1}$. An air-zero source composed of a pump connected to an activated carbon filter to clean the air entering the system of any VOCs was used. The other extremity of the glass bottle was connected to an analyzer-generator in the analyzer mode, where air was extracted at a flow rate of $1.5 \mathrm{~L} \cdot \mathrm{min}^{-1}$ to ensure that the desired $\mathrm{O}_{3}$ concentration was present in the bottle. We used exclusively Teflon tubes to connect the pump, the VOC filter, the $\mathrm{O}_{3}$ generator, and analyzer. Ozone was delivered continuously in a flow through the fumigation chamber and individuals were exposed to different concentrations in a randomized order.

\subsection{Does $\mathrm{O}_{3}$ Concentration Affect Pollinator Antenna Sensitivity?}

Sensory input at the pollinator antenna can be monitored using electrophysiology and, more specifically, electroantennographic recordings (EAG). Electroantennograms measure the summed response of all OSNs present in the insect's antenna to a given olfactory stimulus [66]. A change in the amplitude of the depolarization in response to this stimulus indicates that some part of the antennal detection is affected. In order to evaluate if $\mathrm{O}_{3}$ exposure could affect the sensitivity to a given VOC, EAGs were conducted with different doses of synthetic VOCs $(1,10,100$, and $1000 \mu \mathrm{g})$. Previous studies reported that the 
overall intensity of floral scent produced by one inflorescence (or flower) is approximately $0.1 \mu \mathrm{g} \cdot \mathrm{min}^{-1}$ for F. carica [46]. Similar intensities to this measured for F. carica have been found in two plants species pollinated by B. terrestris $[67,68]$. Based on the results of previous studies, we selected synthetic versions of VOCs that are detected by the antenna of our insect species and mediate the attraction toward their host-plants: the monoterpenes linalool (in racemic mixture [S and $\mathrm{R}$ forms, 50:50]) and linalool oxides ( $\mathrm{Z}$ and $\mathrm{E}$ forms furanoid, 50:50) and the benzenoid benzyl alcohol in the specialist fig wasp [46], and the monoterpene R-linalool, the benzenoid benzaldehyde, and the alkyl aldehyde nonanal in the generalist bumblebee $[69,70]$ (see Table S2 for providers and purity of the different compounds). Linalool mixture was used in our study of fig wasps because S-linalool alone is not available commercially. All VOCs were used 100-fold diluted $(v / v)$ using paraffin (Uvasol ${ }^{\circledR}$, Merck, Darmstadt, Germany) as a diluting agent. A piece of filter paper (Whatman No. 1, $1 \times 2 \mathrm{~cm}$ ) impregnated with $10 \mu \mathrm{L}$ of each stimulus solution was inserted into a glass Pasteur pipette (15 cm in length) and used as a stimulus cartridge.

After exposure of pollinators to an ozone-rich environment, samples for EAG were prepared. For fig wasps, the head was cut at the base and, for bumblebee workers, the right antenna was cut after cold-anesthesia. For fig wasps, we used either the right or left antenna. On the contrary, for bumblebee workers, we exclusively used the right antenna owing to asymmetrical performance favoring this antenna, as compared to the left one, in responding to learned VOCs in this species [71]. The head (head base and the tip of one antenna) or antenna was then mounted between glass capillary tubes filled with insect Ringer's solution $\left(\mathrm{NaCl} / \mathrm{KCl} / \mathrm{CaCl}_{2} / \mathrm{NaHCO}_{3}, \mathrm{Na}^{+} 131 \mathrm{mmol} . \mathrm{L}^{-1}, \mathrm{~K}^{+} 5 \mathrm{mmol} . \mathrm{L}^{-1}, \mathrm{Cl}^{-}\right.$ $\left.111 \mathrm{mmol} . \mathrm{L}^{-1}, \mathrm{C}_{3} \mathrm{H}_{5} \mathrm{O}_{3}-29 \mathrm{mmol} . \mathrm{L}^{-1}\right)$, and connected to the silver electrodes of an EAG Kombi Probe PRG-3 (SYNTECH ${ }^{\circledR}$, Kirchzarten, Germany). The antenna was positioned in the middle of a continuous flow of purified and humidified air blowing through a tube for stimulation (435 mL.min ${ }^{-1}$ ). The tip of a Pasteur pipette odor cartridge was inserted into a small hole on the continuous airflow tube. Stimulus was released by a pulse of purified air through the odor cartridge with a pulse duration of $0.5 \mathrm{~s}$ and a flow of $890 \mathrm{~mL} \cdot \mathrm{min}^{-1}$ regulated by a CS-55 Stimulus Controller (Syntech, Kirchzarten, Germany). Data were recorded by a two-channel universal serial bus acquisition controller (Syntech IDAC-2, Kirchzarten, Germany) and analysed using the software GcEad 1.2.5 (Syntech, Kirchzarten, Germany). Each antenna was exposed to four stimulus sequences, in which each sequence consisted of all the selected compounds (i.e., three for the bumblebees, four for the fig wasps) at a given dose and paraffin controls. The sequence doses were always presented to the antenna in ascending order (i.e., 1, 10, 100, and $1000 \mu \mathrm{g}$, respectively). For each sequence, the compounds were used in a randomized order. Paraffin controls were used for the first and last measurements in a sequence. For quantifying the EAG response amplitude, the mean response to the control was subtracted for each sequence.

\subsection{Does $\mathrm{O}_{3}$ Concentration Affect the Attraction of Pollinators to VOCs?}

We used synthetic VOCs rather than scents from real flowers in order to eliminate any possible variability due to the odor source among the tests. For fig wasps, a blend of VOCs mimicking the odor of the fig host and shown to elicit pollinator attraction was used (S-linalool, Z-linalool oxide, E-linalool oxide, and benzyl alcohol in the proportion of $76.34 \%, 0.38 \%, 0.38 \%$, and $22.90 \%$, respectively [46]). For bumblebees, benzaldehyde alone was used as it was the VOC eliciting the highest electroantennographic response and whose detection was the most affected by $\mathrm{O}_{3}$, according to our EAG experiments. Behavioral assays were carried out in a dynamic airflow glass Y-tube olfactometer to evaluate preferences for odor against clean-air control (i.e., dual-choice scenario) following a protocol similar to that used by Proffit et al. [46]. The odor diffuser released VOCs, on average, at $65.92 \mathrm{ng} \cdot \mathrm{min}^{-1}$ for the fig wasp mix and $270 \mathrm{ng} \cdot \mathrm{min}^{-1}$ for benzaldehyde. After exposure to $\mathrm{O}_{3}$ (see Table S3 for details about exposure conditions and sample sizes), pollinators were introduced into the stem of the Y-tube, tested individually, and used only once. 
Due to behavioral differences between fig wasps and bumblebees owing to their different ecological traits, behavioral assays were adapted for each model. For fig wasps, the behavioral assays were carried out in a dark room using a light source (18 lumens light intensity) above the olfactometer and above the glass containers containing the odor source. Each trial stopped after the fig wasp had entered one of the arms and went to the top of the chosen arm. We considered that wasps did not choose when they stayed motionless for ten minutes in the departure section and/or the central arm before the bifurcation of the olfactometer. These individuals were then discarded and not taken into account in the statistical analyses. For the bumblebees, the behavioral assays were performed under red light and recorded for 10 min using a USB HD 720p camera (Logitech, Lausanne, Switzerland). The number of bouts toward the far end of each of the arms of the Y-tube was counted (i.e., complete bouts). Incomplete bouts (i.e., entering an arm but not going to the far end) were not taken into account. The workers performed between 3 and 45 complete bouts per assay.

\subsection{Statistical Analyses}

All analyses were performed in R version 3.4.0 [72].

\subsubsection{Pollinator Antenna Sensitivity}

To test for differences in the antennal response among $\mathrm{O}_{3}$ exposures, linear mixed models were computed for each compound with $\mathrm{O}_{3}$ treatment and VOC dose as fixed effects and individual (nested in colony for bumblebees) as a random factor (R-package "nlme", [73]). Data were log-transformed to achieve normality of residuals. Contrasts between regressions were then performed to determine whether antennal response to a specific VOC dose differed according to the $\mathrm{O}_{3}$ treatment (R-package "contrast"; $[74,75]$ ). The same analyses were performed on datasets for both the fig wasps and the bumblebees.

\subsubsection{Attraction of Pollinators to VOCs}

Choice by fig wasps between clean-air control and odor source in the Y-tube olfactometer was analysed for each $\mathrm{O}_{3}$ exposure using two-sided binomial tests to investigate whether the wasp distribution differed from 50:50. Regarding bumblebee behavior, we compared the number of complete bouts in each arm for each $\mathrm{O}_{3}$ exposure, by using paired-samples Wilcoxon signed-rank tests. We then tested for differences in a behavioral response among $\mathrm{O}_{3}$ exposures using general linear models with $\mathrm{O}_{3}$ treatment as a fixed effect and colony as a random factor (R-package "lmerTest", [73]). We used a binomial model with the number of complete bouts toward the benzaldehyde (successes) and the number of complete bouts toward the clean-air control (failures) as a bivariate response after checking for overdispersion. When a significant effect was found, multiple pairwise comparison tests were performed using Tukey contrasts and FDR adjustment to determine which $\mathrm{O}_{3}$ treatments significantly differed from each other (R-package "multcomp", [76]).

\section{Results}

3.1. Does $\mathrm{O}_{3}$ Concentration Affect Pollinator Antenna Sensitivity?

\subsubsection{Fig Wasp System}

The electroantennographic recordings show different antennal responses depending on $\mathrm{O}_{3}$ exposures and the VOCs tested. After $60 \mathrm{~min}$ or $180 \mathrm{~min}$ of $\mathrm{O}_{3}$ exposure, we detected significant changes compared to the control in the amplitude of antennal response for at least one of the tested doses of each VOC used, except for the linalool oxides, where no significant changes were detected (Figure 1, Table S4). After 60-min exposure to $200 \mathrm{ppb}$ $\mathrm{O}_{3}$, a significant difference from the control was found for benzyl alcohol at $1000 \mu \mathrm{g}$, with an increased antennal response after $\mathrm{O}_{3}$ exposure. For the other doses of the VOCs tested, the EAG responses were not significantly different from the control. In contrast, the effect of 180-min $\mathrm{O}_{3}$ exposure led to a decrease of the antennal response of fig wasps, depending on the $\mathrm{O}_{3}$ level and the VOC dose, except for the linalool oxides, where no significant 
changes were detected (Figure 1). Responses to benzyl alcohol and linalool mixture were all significantly lower after $\mathrm{O}_{3}$ exposure (either at $80 \mathrm{ppb}, 120 \mathrm{ppb}$ or both), for at least one of the tested VOC doses.

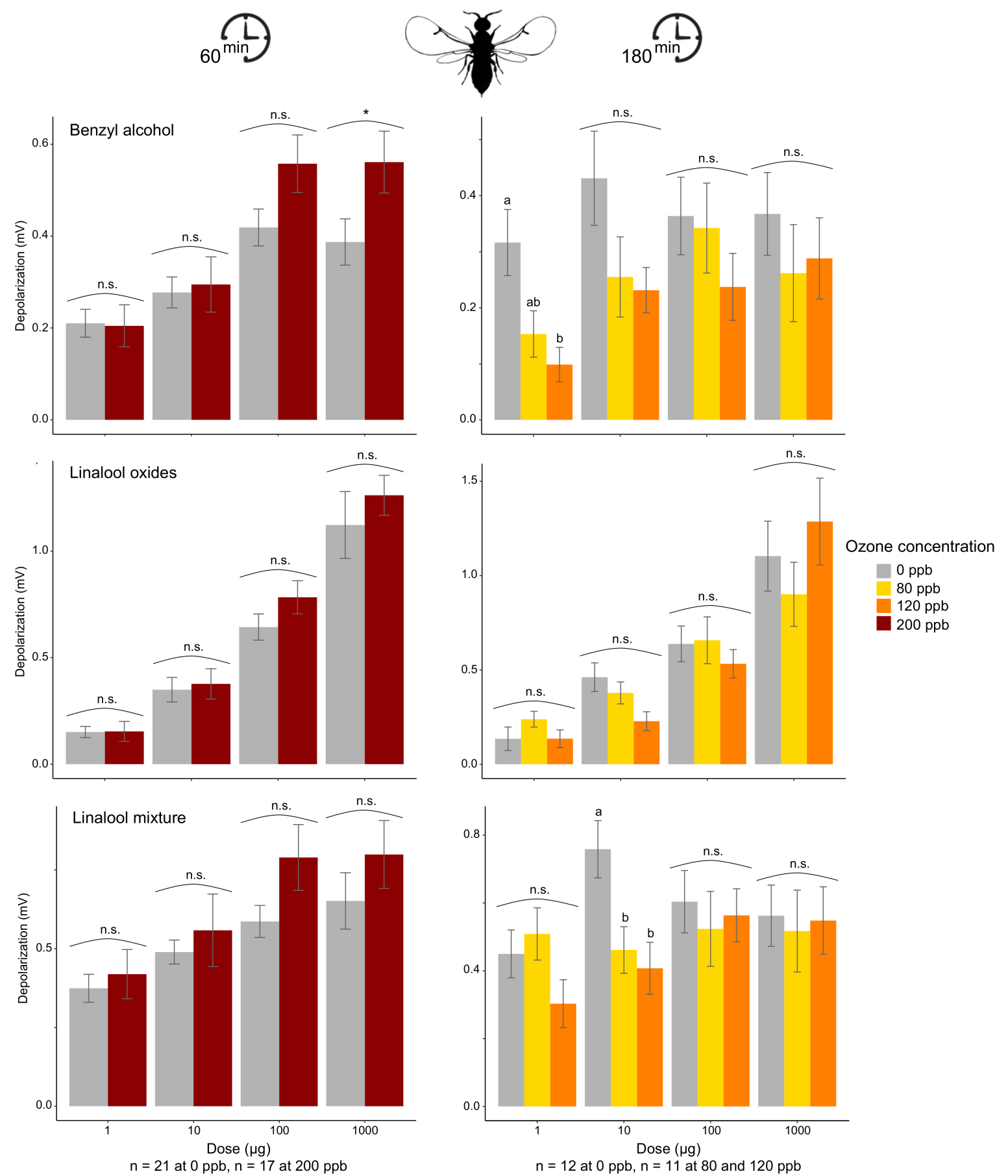

Figure 1. The effect of $\mathrm{O}_{3}$ exposure on the electroantennographic (EAG) responses (mean $\pm \mathrm{SE}$ ) of fig wasps to different doses of four synthetic volatile compounds ( $n$, number of specimens tested). Prior to the EAG recording, wasps were exposed to different $\mathrm{O}_{3}$ concentrations for 60 -min or 180-min. Different letters (n.s. $p>0.05$ ) or asterisks $\left({ }^{*} p<0.05\right)$ indicate significant differences in the EAG response to one compound at a given dose between $\mathrm{O}_{3}$ treatments based on contrasts.

\subsubsection{Bumblebee System}

The electroantennographic recording revealed that $\mathrm{O}_{3}$ decreased the antennal response for all three VOCs in some of the tested conditions. The exact quantitative effect of $\mathrm{O}_{3}$ 
concentration, and whether this decrease depended on the duration of $\mathrm{O}_{3}$ exposure, varied depending on the VOC tested and its dose (Figure 2, Table S5). After 60 min, the antennal response overall decreased with increasing exposure to $\mathrm{O}_{3}$, when VOCs were presented at high doses $(100 \mu \mathrm{g}$ and $1000 \mu \mathrm{g})$, with the exception of benzaldehyde. For this latter, at doses of 10,100 , and $1000 \mu \mathrm{g}$, the antennal response of workers decreased after exposure at 80 and $120 \mathrm{ppb} \mathrm{O}_{3}$ while it slightly re-grew after 200 ppb exposure (i.e., U-shaped response, Figure 2). Impact of $\mathrm{O}_{3}$ exposure seemed to be less marked on insects that were exposed for $180 \mathrm{~min}$. In these cases, a significant decrease in an antennal response was found for only two VOCs, at doses of 100 and $1000 \mu \mathrm{g}$.

\subsection{Does $\mathrm{O}_{3}$ Concentration Affect the Attraction of Pollinators to VOCs?}

\subsubsection{Fig Wasp System}

The orientation of the fig wasps toward the blend mimicking host odor was affected after both $60 \mathrm{~min}$ and $180 \mathrm{~min}$ exposure to $\mathrm{O}_{3}$ for at least one of the $\mathrm{O}_{3}$ concentrations. At 0 and $80 \mathrm{ppb} \mathrm{O}_{3}$, individuals significantly preferred the VOC blend, mimicking the odor of receptive figs over the clean air $(0 \mathrm{ppb}, 60$-min exposure, $p=0.015,0 \mathrm{ppb}, 180$-min exposure, $p=0.033,80 \mathrm{ppb}, 180$-min exposure $p=0.015$, Figure 3). At $120 \mathrm{ppb} \mathrm{O}_{3}$, fig wasps had no preference for either side of the Y-tube (60-min exposure, $p=0.480,180$-min exposure, $p=0.888$ ) while they significantly preferred the clean air over the VOC mix when exposed to $200 \mathrm{ppb} \mathrm{O}_{3}(60$-min exposure, $p=0.044)$ (Figure 3).

\subsubsection{Bumblebee System}

The orientation responses of naive bumblebee foragers to benzaldehyde were significantly affected by $\mathrm{O}_{3}$ exposure $\left(\chi^{2}=10.086, \mathrm{df}=3, p=0.018\right.$, Figure 4$)$. The number of bouts toward the benzaldehyde was significantly higher than the number of bouts toward the clean air for the control treatment $(0 \mathrm{ppb})(\mathrm{V}=80.5, p=0.003)$. When exposed to $\mathrm{O}_{3}$, whatever the $\mathrm{O}_{3}$ concentration tested, the foragers lost their preference for the benzaldehyde and oriented as frequently toward the synthetic volatile compound as to clean air $(p>0.05$, Figure 4). 


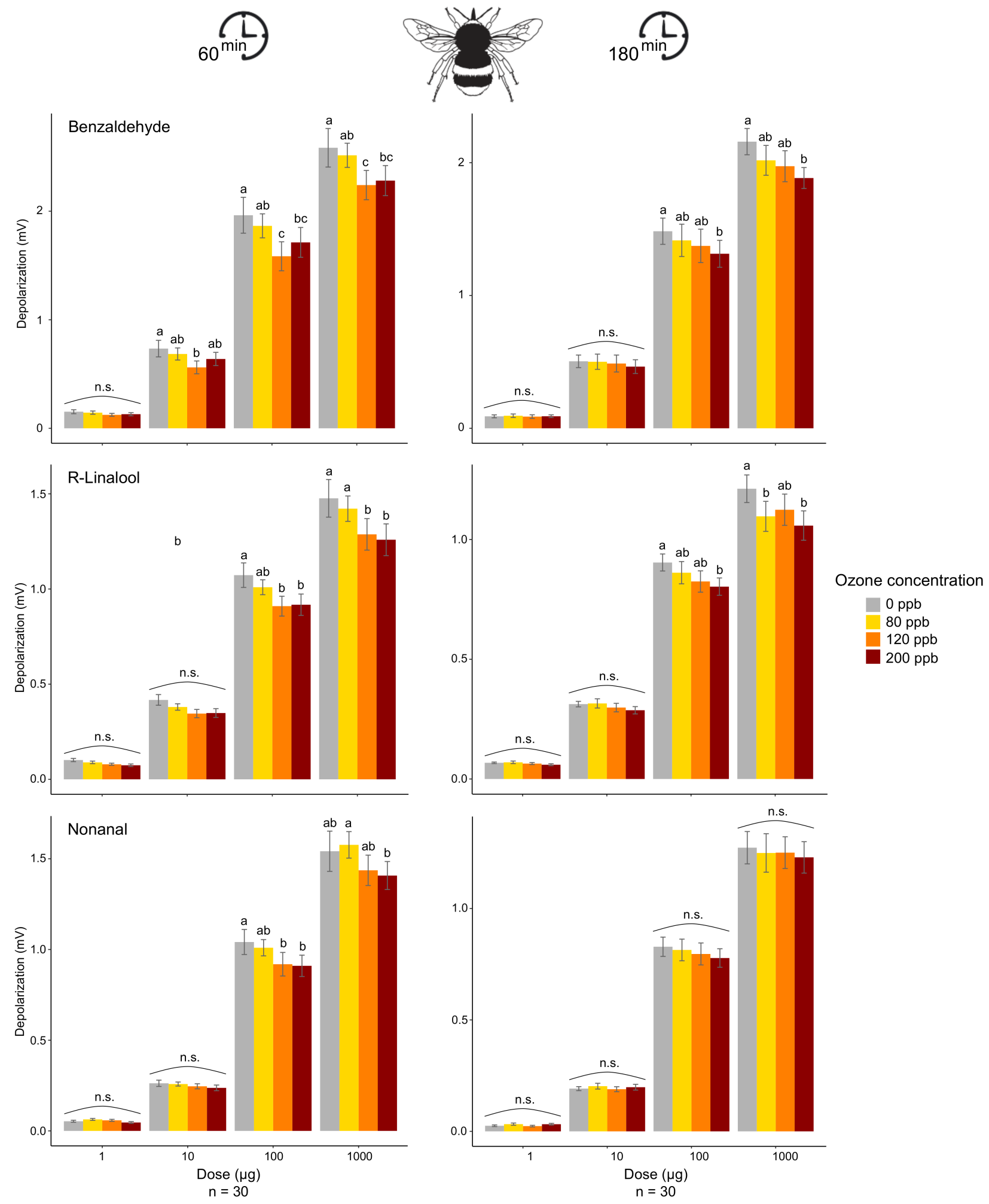

Figure 2. Effect of $\mathrm{O}_{3}$ exposure on the electroantennographic (EAG) responses (mean $\pm \mathrm{SE}$ ) of bumblebee foragers to different doses of three synthetic compounds ( $n$, number of specimens tested). Prior to the EAG recording, bumblebees were exposed to different $\mathrm{O}_{3}$ concentrations for 60-min or 180-min. Different letters ( $\mathrm{a}$ and $\mathrm{b}$ ) indicate significant differences $(p<0.05)$ in the EAG response to one compound at a given dose between $\mathrm{O}_{3}$ concentrations based on contrast analysis. 

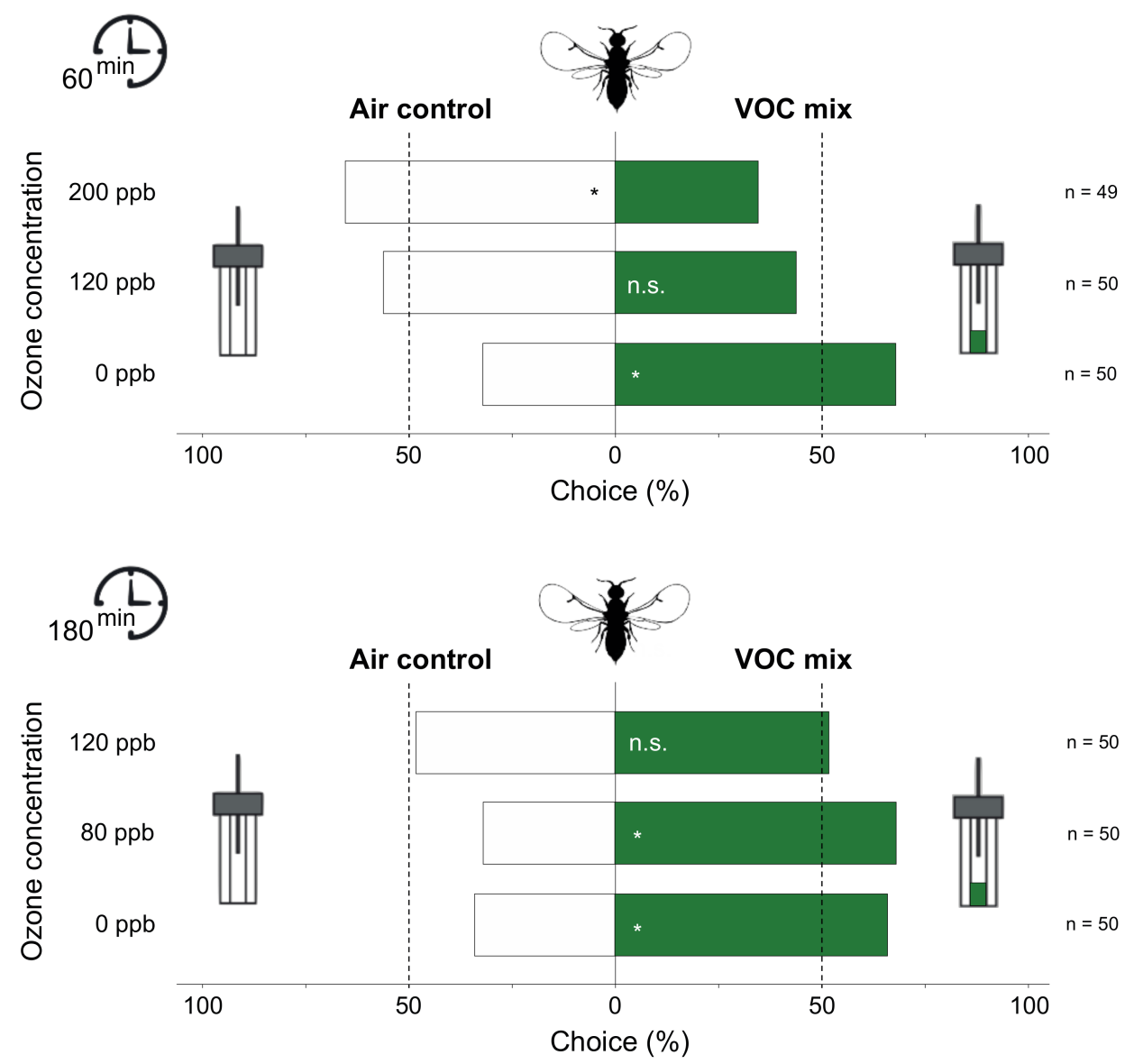

Figure 3. Effect of $\mathrm{O}_{3}$ exposure on the attraction of fig wasps to the VOC mix mimicking fig odor or clean air in Y-tube olfactometers (n, number of specimens tested). Prior to the behavioral test, wasps were exposed to different $\mathrm{O}_{3}$ concentrations for 60 -min or 180-min. Asterisks indicate a significant preference based on two-sided binomial tests $\left({ }^{*} p<0.05\right)$.

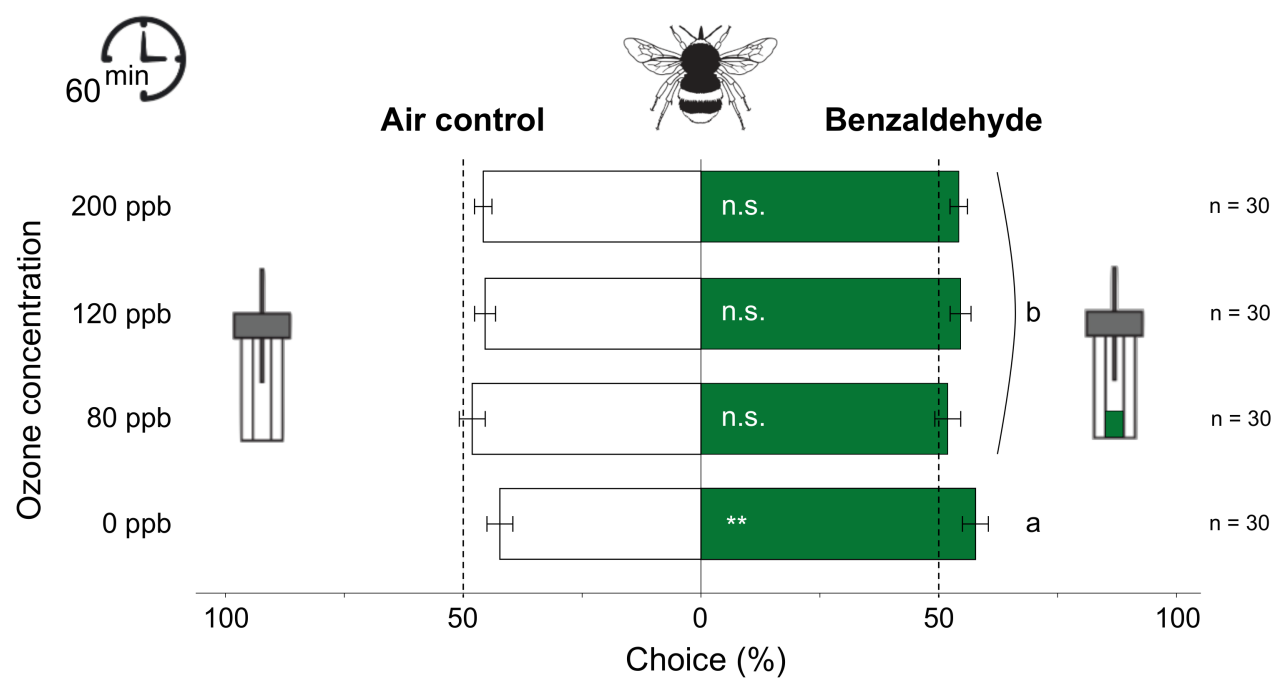

Figure 4. Effect of 60-min $\mathrm{O}_{3}$ exposure on the attraction (mean $\pm \mathrm{SE}$ based on the percentage of bouts) of bumblebee foragers to benzaldehyde or clean air in Y-tube olfactometers ( $n$, number of specimens tested). Asterisks indicate a preference, according to the paired Wilcoxon signed-rank tests $\left.{ }^{* *} p<0.01\right)$, and different letters indicate a significant difference in choice among $\mathrm{O}_{3}$ treatments, according to the multiple pairwise comparisons based on the binomial model $(p<0.05)$. 


\section{Discussion}

In two pollinator species differing in their ecological traits, this study revealed an effect of exposure to high $\mathrm{O}_{3}$ concentration on their ability to detect and react to VOCs contained in floral scents of their associated plants. Effects of $\mathrm{O}_{3}$ pollution on the emission of VOCs by plants and on their lifetime in the atmosphere have already been demonstrated [37,42-44], but without testing the possible additional effects on the pollinator itself [21]. Our findings provide new information on the impact of air pollution on plant-pollinator chemical communication and underline an additional threat for pollination of entomogamous plant species.

The electrophysiological experiments revealed that an increase in $\mathrm{O}_{3}$ concentrations affects VOC detection by the antenna to different substances depending on exposure duration, VOC identity, and its dose, with some patterns in the antennal responses differing between the two insect species tested. For bumblebee workers, with the increase of the $\mathrm{O}_{3}$ concentration, there was a progressive reduction in the amplitude of antennal response to most VOCs tested, when these were present at their higher doses (i.e., 100 and $1000 \mu \mathrm{g}$ ), with a more pronounced effect after $60 \mathrm{~min}$ of $\mathrm{O}_{3}$ exposure compared to $180 \mathrm{~min}$. For fig wasps, both times of exposure showed an impact on antennal response but with contrasted effects. After $180 \mathrm{~min}$ of exposure to intermediate and high concentrations, the antennal detection decreased progressively with increasing $\mathrm{O}_{3}$ concentration for most VOCs but mainly for their lower doses (i.e., 1 and $10 \mu \mathrm{g}$ ). In contrast, after $60 \mathrm{~min}$ of exposure to a very high $\mathrm{O}_{3}$ concentration, the antennal responses clearly increased compared to the control for most VOCs, but mainly for their higher doses (i.e., 100 and $1000 \mu \mathrm{g}$ ). On the other hand, in both species, the antennal detection of some VOCs seemed not to be affected by $\mathrm{O}_{3}$ exposure. These complex and unpredictable observations emphasize the need to increase our knowledge of the mode of $\mathrm{O}_{3}$ action on insect antenna.

Although the underlying mechanisms of $\mathrm{O}_{3}$ action on the perception of VOCs by the insect antenna have not been investigated in this study, some hypotheses can be proposed. It is already known that $\mathrm{O}_{3}$ reacts with proteins (e.g., oxidation of the polypeptide backbone, peptide bond cleavage, protein-protein cross-linking, and modifications of amino acid side chain), altering their structure and their functional properties [77]. Ozone may, thus, oxidize proteins involved in olfaction [78], affecting the insect's sensitivity to VOCs. Such effects of significant damage to the peripheral olfactory system have been reported in the case of exposure to high doses of insecticide. For instance, in honeybees, high doses of some insecticides strongly increased OSN repolarization time by prolonging sodium channel opening [79] and delaying signal termination. Such phenomena should lead to an increased amplitude of the EAG response. Regarding the U-shaped pattern observed in the antennal response of bumblebees to some VOCs (i.e., a decrease at intermediate-high concentrations followed by a re-increase at a very high concentration), it could be partly explained by an endocrine regulation of antioxidative reactions [80-83].

Since the effect of $\mathrm{O}_{3}$ on VOC detection varies with both the different VOCs (VOCvarying effect) and their concentration (dose-varying effect), it should change the insect's overall perception of the odor blend. As the relative proportions of the various VOCs constitute the authentic scent cue and is crucial for pollinator attraction [46], such a differential change could disrupt the orientation of pollinators to their host plants. Accordingly, the results of the behavioral assays showed that exposure to high and very high $\mathrm{O}_{3}$ concentrations reduced the ability of pollinators to orient toward an odor source attractive in control conditions for both pollinator species. In addition, exposure to intermediate $\mathrm{O}_{3}$ concentration also affects the attraction of bumblebees to benzaldehyde. Most intriguingly, we showed that an initially attractive VOC blend might even be avoided by the fig wasp after exposure to realistic but very high $\mathrm{O}_{3}$ concentration. This might be due to an important alteration of the antennal OSNs or other physiological features. Exposure of pollinators to $\mathrm{O}_{3}$ may induce other damages such as oxidation of non-antennal proteins, lipid peroxidation, and damage to DNA, but also deregulation of intracellular signal transduction, which could disrupt the entire organism and lead to death (reviewed in Reference [84]). 
The combined effects of $\mathrm{O}_{3}$ on (i) the signal sending (direct effects on plant volatile emission, e.g., [41]), (ii) the degradation and dispersion of VOCs (reactions in the atmosphere; e.g., [43]), and (iii) the ability of pollinators to detect and respond to volatiles cues (direct effects on receiver organisms, present study) could have a significant impact on the efficiency of plant-pollinator interactions and then on fitness of both partners [21]. Our study showed that $\mathrm{O}_{3}$ pollution exposure does not impact all pollinator species equally (i.e., detection abilities and behavioral responses). Especially, the fig wasps appear to be less resilient than the bumblebees to $\mathrm{O}_{3}$ exposure, with a higher impact on the behavioral response. Such difference in species vulnerability is likely associated with their ecological traits (e.g., size, longevity, and feeding behavior). Compared to the fig wasps that cannot feed at the adult stage, bumblebees may benefit from a protective effect of dietary antioxidants as well from energy intake to activate endogenous antioxidant defenses that are costly for the organism [85-87]. This advantage will likely give them an extra chance to recover from the oxidative stress triggered by $\mathrm{O}_{3}$ exposure. Moreover, fig wasps have a limited possibility of recovery given their reduced lifespan that should likely not allow the activation of the endogenous antioxidant machinery that is likely to take time [88].

Evidence is that $\mathrm{O}_{3}$ can affect all levels of the volatile-mediated interaction between plants and pollinators. Future research should adopt an approach that integrates mechanistic studies to elucidate the mode of $\mathrm{O}_{3}$ action on insect antenna, the physiological response of insects (endogenous antioxidant defense mechanisms), and the possibility for nutritional resilience (exogenous dietary antioxidant intake). For completing the picture, future research should also consider the diversity of ecological traits of species as well as the diversity of natural conditions (spatial and temporal dynamics) to understand how $\mathrm{O}_{3}$ can affect ecosystem functioning, and to reduce the impact of anthropogenic oxidants on plant-pollinator systems through pertinent conservation actions.

Supplementary Materials: The following are available online at https://www.mdpi.com/article/ 10.3390/antiox10050636/s1. Table S1: Conditions of $\mathrm{O}_{3}$ exposure and sample sizes for electrophysiological experiments. Table S2: Provider, CAS (Chemical Abstracts Service) number, and purity of the synthetic VOCs used during the experiments. Table S3: Conditions of ozone exposure and sample sizes for behavioral assays. Table S4: Statistical outputs ( $p$-values) regarding the impact of $\mathrm{O}_{3}$ exposure on antennal sensitivity in fig wasps. Table S5: Statistical outputs ( $p$-values) regarding the impact of $\mathrm{O}_{3}$ exposure on antennal sensitivity in bumblebee workers.

Author Contributions: M.P., M.V., M.D., M.H.-M., and B.L. designed the study. M.V., B.L., M.B., M.O., and M.P. collected the data. M.V., B.L., and M.P. analyzed the data. M.V. wrote the first draft of the manuscript, and all authors contributed substantially to revisions. All authors have read and agreed to the published version of the manuscript.

Funding: This work is a contribution to the French National Research Program for Environmental and Occupational Health of ANSES (2018/1/138), and was partly funded by the International Research Project (IRP)-CNRS-MOST and by the French National Research Agency (ANR) under the program "Investissements d'avenir" (reference ANR-16-IDEX-0006).

Institutional Review Board Statement: Not applicable.

Informed Consent Statement: Not applicable.

Data Availability Statement: The data presented in this study are available on request from the corresponding author.

Acknowledgments: We thank D. Evrard for his valuable help during the experiment, Biobest for providing the bumblebee colonies, B. Buatois and N. Barthès from the Platform for Chemical Analysis in Ecology (PACE, LabEx CeMEB, ANR under the program "Investissements d'avenir") at the CEFE (Centre of Functional and Evolutionary Ecology, Montpellier, France), D. McKey (native speaker) for English proofreading, and C. Violle, D. Carrasco and five anonymous referees for their constructive comments on the manuscript. 
Conflicts of Interest: The authors declare no conflict of interest. The funders had no role in the design of the study, in the collection, analyses, or interpretation of data, in the writing of the manuscript, or in the decision to publish the results.

\section{References}

1. Parmesan, C. Ecological and evolutionary responses to recent climate change. Annu. Rev. Ecol. Evol. Syst. 2006, 37, 637-669. [CrossRef]

2. Yuan, J.S.; Himanen, S.J.; Holopainen, J.K.; Chen, F.; Stewart, C.N., Jr. Smelling global climate change: Mitigation of function for plant volatile organic compounds. Trends Ecol. Evol. 2009, 24, 323-331. [CrossRef] [PubMed]

3. Potts, S.G.; Biesmeijer, J.C.; Kremen, C.; Neumann, P.; Schweiger, O.; Kunin, W.E. Global pollinator declines: Trends, impacts and drivers. Trends Ecol. Evol. 2010, 25, 345-353. [CrossRef] [PubMed]

4. Klein, A.-M.; Vaissière, B.E.; Cane, J.H.; Steffan-Dewenter, I.; Cunningham, S.A.; Kremen, C.; Tscharntke, T. Importance of pollinators in changing landscapes for world crops. Proc. R. Soc. B 2007, 274, 303-313. [CrossRef] [PubMed]

5. Gallai, N.; Salles, J.-M.; Settele, J.; Vaissière, B. Economic valuation of the vulnerability of world agriculture confronted to pollinator decline. Ecol. Econ. 2009, 68, 810-821. [CrossRef]

6. IPBES. The Methodological Assessment Report on Scenarios and Models of Biodiversity and Ecosystem Services: Summary for Policymakers; Ferrier, S., Ninan, K.N., Leadley, P., Alkemade, R., Acosta, L.A., Akçakaya, H.R., Brotons, L., Cheung, W., Christensen, V., Harhash, K.A., Eds.; Intergovernmental Science-Policy Platform on Biodiversity and Ecosystem Services: Bonn, Germany, 2016.

7. Girling, R.D.; Lusebrink, I.; Farthing, E.; Newman, T.A.; Poppy, G.M. Diesel exhaust rapidly degrades floral odours used by honeybees. Sci. Rep. 2013, 3, 2779. [CrossRef] [PubMed]

8. Lusebrink, I.; Girling, R.D.; Farthing, E.; Newman, T.A.; Jackson, C.W.; Poppy, G.M. The effects of diesel exhaust pollution on floral volatiles and the consequences for honey bee olfaction. J. Chem. Ecol. 2015, 41, 904-912. [CrossRef] [PubMed]

9. IPCC. Climate Change 2013: The Physical Science Basis. Contribution of Working Group I to the Fifth Assessment Report of the Intergovernmental Panel on Climate Change; Stocker, T.F.D., Qin, G.-K., Plattner, M., Tignor, S.K., Allen, J., Boschung, A., Nauels, Y., Xia, V.B., Midgley, P.M., Eds.; Cambridge University Press: New York, NY, USA, 2013; 1535p.

10. Mills, G.; Pleijel, H.; Malley, C.S.; Sinha, B.; Cooper, O.R.; Schultz, M.G.; Neufeld, H.S.; Simpson, D.; Sharps, K.; Feng, Z.; et al. Tropospheric Ozone Assessment Report: Present-day tropospheric ozone distribution and trends relevant to vegetation. Elem. Sci. Anthrop. 2018, 6, 47. [CrossRef]

11. Paoletti, E. Impact of ozone on Mediterranean forests: A review. Environ. Pollut. 2006, 144, 463-474. [CrossRef] [PubMed]

12. The Royal Society. Ground-Level Ozone in the 21st Century: Future Trends, Impacts and Policy Implications; The Royal Society: London, UK, 2008; 132p.

13. Cooper, O.R.; Parrish, D.D.; Ziemke, J.; Balashov, N.V.; Cupeiro, M.; Galbally, I.E.; Gilge, S.; Horowitz, L.; Jensen, N.R.; Lamarque, J.-F.; et al. Global distribution and trends of tropospheric ozone: An observation-based review. Elem. Sci. Anthrop. 2014, 2, 000029. [CrossRef]

14. Lei, H.; Wuebbles, D.J.; Liang, X.Z. Projected risk of high ozone episodes in 2050. Atmos. Environ. 2012, 59, 567-577. [CrossRef]

15. Gryparis, A.; Forsberg, B.; Katsouyanni, K.; Analitis, A.; Touloumi, G.; Schwartz, J.; Samoli, E.; Medina, S.; Andersib, H.R.; Niciu, E.M.; et al. Acute effects of ozone on mortality from the «air pollution and health: A European approach» project. Am. J. Respir. Crit. Care Med. 2004, 170, 1080-1087. [CrossRef]

16. Iriti, M.; Faoro, F. Oxidative stress, the paradigm of ozone toxicity in plants and animals. Water Air Soil Pollut. 2008, 187, 285-301. [CrossRef]

17. WHO Regional Office for Europe. Review of Evidence on Health Aspects of Air Pollution-REVIHAAP Project; Technical Report; WHO Regional Office for Europe: Copenhagen, Denmark, 2013; pp. 1-309.

18. Babadjouni, R.M.; Hodis, D.M.; Radwanski, R.; Durazo, R.; Patel, A.; Liu, Q.; Mack, W.J. Clinical effects of air pollution on the central nervous system: A review. J. Clin. Neurosci. 2017, 43, 16-24. [CrossRef]

19. Mills, G.; Sharps, K.; Simpson, D.; Pleijel, H.; Broberg, M.; Uddling, J.; Jaramillo, F.; Davies, W.J.; Dentener, F.; van den Berg, M.; et al. Ozone pollution will compromise efforts to increase global wheat production. Glob. Chang. Biol. 2018, 24, 3560-3574. [CrossRef]

20. Agathokleous, E.; Feng, Z.; Oksanen, E.; Sicard, P.; Wang, Q.; Saitanis, C.J.; Araminiene, V.; Blande, J.D.; Hayes, F.; Calatayud, V.; et al. Ozone affects plant, insect, and soil microbial communities: A threat to terrestrial ecosystems and biodiversity. Sci. Adv. 2020, 6, eabc1176. [CrossRef]

21. Blande, J.D. Effects of air pollution on plant-insect interactions mediated by olfactory and visual cues. Curr. Opin. Environ. Sci. Health 2021, 19, 100228.

22. Williams, N.M.; Crone, E.E.; Roulston, T.H.; Minckley, R.L.; Packer, L.; Potts, S.G. Ecological and life-history traits predict bee species responses to environmental disturbances. Biol. Conserv. 2010, 143, 2280-2291. [CrossRef]

23. Bartomeus, I.; Ascher, J.S.; Gibbs, J.; Danforth, B.N.; Wagner, D.L.; Hedtke, S.M.; Winfree, R. Historical changes in northeastern US bee pollinators related to shared ecological traits. Proc. Natl. Acad. Sci. USA 2013, 110, 4656-4660. [CrossRef]

24. Greenleaf, S.S.; Williams, N.M.; Winfree, R.; Kremen, C. Bee foraging ranges and their relationship to body size. Oecologia 2007, 153, 589-596. [CrossRef] 
25. Bommarco, R.; Biesmeijer, J.C.; Meyer, B.; Potts, S.G.; Pöyry, J.; Roberts, S.P.M.; Steffan-dewenter, I.; Öckinger, E. Dispersal capacity and diet breadth modify the response of wild bees to habitat loss. Proc. R. Soc. B Biol. Sci. 2010, 277, 2075-2082. [CrossRef]

26. Jauker, B.; Krauss, J.; Jauker, F.; Steffan-Dewenter, I. Linking life history traits to pollinator loss in fragmented calcareous grasslands. Landsc. Ecol. 2013, 28, 107-120. [CrossRef]

27. Hopfenmüller, S.; Steffan-Dewenter, I.; Holzschuh, A. Trait-specific responses of wild bee communities to landscape composition, configuration and local factors. PLoS ONE 2014, 9, e104439. [CrossRef]

28. Li-Byarlay, H.; Huang, M.H.; Simone-Finstrom, M.; Strand, M.K.; Tarpy, D.R.; Rueppell, O. Honey bee (Apis mellifera) drones survive oxidative stress due to increased tolerance instead of avoidance or repair of oxidative damage. Exp. Gerontol. 2016, 83, 15-21. [CrossRef]

29. Tasaki, E.; Kobayashi, K.; Matsuura, K.; Iuchi, Y. An efficient antioxidant system in a long-lived termite queen. PLoS ONE 2017, 12, e0167412. [CrossRef]

30. Aličić, D.; Šubarić, D.; Jašić, M.; Pašalić, H.; Ačkar, Đ. Antioxidant properties of pollen. Hrana u Zdravlju i Bolesti $2014,3,6-12$.

31. Raguso, R.A. Wake up and smell the roses: The ecology and evolution of floral scent. Annu. Rev. Ecol. Evol. Syst. 2008, 39, 549-569. [CrossRef]

32. Hossaert-McKey, M.; Soler, C.; Schatz, B.; Proffit, M. Floral scents: Their roles in nursery pollination mutualisms. Chemoecology 2010, 20, 75-88. [CrossRef]

33. Conchou, L.; Lucas, P.; Meslin, C.; Proffit, M.; Staudt, M.; Renou, M. Insect odorscapes: From plant volatiles to natural olfactory scenes. Front. Physiol. 2019, 10, 425. [CrossRef]

34. Laothawornkitkul, J.; Taylor, J.E.; Paul, N.D.; Hewitt, C.N. Biogenic volatile organic compounds in the Earth system. New Phytol. 2009, 183, 27-51. [CrossRef]

35. McFrederick, Q.S.; Fuentes, J.D.; Roulston, T.; Kathilankal, J.C.; Lerdau, M. Effects of air pollution on biogenic volatiles and ecological interactions. Oecologia 2009, 160, 411-420. [CrossRef] [PubMed]

36. Pinto, D.M.; Blande, J.D.; Souza, S.R.; Nerg, A.-M.; Holopainen, J.K. Plant volatile organic compounds (VOCs) in ozone (O 3$)$ polluted atmospheres: The ecological effects. J. Chem. Ecol. 2010, 36, 22-34. [CrossRef] [PubMed]

37. Blande, J.D.; Holopainen, J.K.; Niinemets, Ü. Plant volatiles in polluted atmospheres: Stress responses and signal degradation. Plant Cell Environ. 2014, 37, 1892-1904. [CrossRef] [PubMed]

38. Wilson, J.K.; Kessler, A.; Woods, H.A. Noisy communication via airborne infochemicals. BioScience 2015, 65, 667-677. [CrossRef]

39. Loreto, F.; Schnitzler, J.-P. Abiotic stresses and induced BVOCs. Trends Plant Sci. 2010, 15, 154-166. [CrossRef]

40. Jamieson, M.A.; Burkle, L.A.; Manson, J.S.; Runyon, J.B.; Trowbridge, A.M.; Zientek, J. Global change effects on plant-insect interactions: The role of phytochemistry. Curr. Opin. Insect Sci. 2017, 23, 70-80. [CrossRef]

41. Saunier, A.; Blande, J.D. The effect of elevated ozone on floral chemistry of Brassicaceae species. Environ. Pollut. 2019, $255,113257$. [CrossRef]

42. Blande, J.D.; Holopainen, J.K.; Li, T. Air pollution impedes plant-to-plant communication by volatiles. Ecol. Lett. 2010, 13, 1172-1181. [CrossRef]

43. Farré-Armengol, G.; Peñuelas, J.; Li, T.; Yli-Pirilä, P.; Filella, I.; Llusia, J.; Blande, J.D. Ozone degrades floral scent and reduces pollinator attraction to flowers. New Phytol. 2016, 209, 152-160. [CrossRef]

44. Fuentes, J.; Chamecki, M.; Roulston, T.; Chen, B.; Pratt, K.R. Air pollutants degrade floral scents and increase insect foraging times. Atmos. Environ. 2016, 141, 361-374. [CrossRef]

45. Bruce, T.J.; Wadhams, L.J.; Woodcock, C.M. Insect host location: A volatile situation. Trends Plant Sci. 2005, 10, 269-274. [CrossRef]

46. Proffit, M.; Lapeyre, B.; Buatois, B.; Deng, X.; Arnal, P.; Gouzerth, F.; Carrasco, D.; Hossaert-McKey, M. Chemical signal is in the blend: Bases of plant-pollinator encounter in a highly specialized interaction. Sci. Rep. 2020, 10, 10071. [CrossRef]

47. Hansson, B.S.; Stensmyr, M.C. Evolution of insect olfaction. Neuron 2011, 72, 698-711. [CrossRef]

48. Owald, D.; Felsenberg, J.; Talbot, C.B.; Das, G.; Perisse, E.; Huetteroth, W.; Waddell, S. Activity of defined mushroom body output neurons underlies learned olfactory behavior in Drosophila. Neuron 2015, 86, 417-427. [CrossRef]

49. Schultzhaus, J.; Saleem, S.; Iftokhar, H.; Carney, G.E. The role of the Drosophila lateral horn in olfactory information processing and behavioral response. J. Insect Physiol. 2017, 98, 29-37. [CrossRef]

50. Dötterl, S.; Vater, M.; Rupp, T.; Held, A. Ozone differentially affects perception of plant volatiles in western honey bees. J. Chem. Ecol. 2016, 42, 486-489. [CrossRef]

51. Kjellberg, F.; Doumesche, B.; Bronstein, J.L. Longevity of a fig wasps (Blastophaga psenes). Proc. K. Ned. Akd. Wet. Ser. C Biol. Med. Sci. 1988, 91, 117-122.

52. Kjellberg, F.; Lesne, A. Ficus carica and Its Pollination. Master, France. 2020. hal-02516888. Available online: https://hal.archivesouvertes.fr/hal-02516888/file/Ficus_carica_and_its_pollination_2020_03_21.pdf (accessed on 7 January 2021).

53. Rodd, F.H.; Plowright, R.C.; Owen, R.E. Mortality rates of adult bumble bee workers (Hymenoptera: Apidae). Can. J. Zool. 1980, 58, 1718-1721. [CrossRef]

54. Schmid-Hempel, P.; Heeb, D. Worker mortality and colony development in bumblebees, B. lucorum L. Mitt. Schweiz Entomol. Ges. 1991, 64, 93-108.

55. Kleijn, D.; Raemakers, I. A retrospective analysis of pollen host plant use by stable and declining bumble bee species. Ecology 2008, 89, 1811-1823. [CrossRef] 
56. Rasmont, P.; Coppée, A.; Michez, D.; de Meleumeester, T. An overview of the Bombus terrestris (L. 1758) subspecies (Hymenoptera: Apidae). Ann. Soc. Entomol. Fr. 2008, 44, 243-250. [CrossRef]

57. Leonhardt, S.D.; Blüthgen, N. The same, but different: Pollen foraging in honeybee and bumblebee colonies. Apidologie 2012, 43, 449-464. [CrossRef]

58. Mazzeo, G.; Bella, S.; Seminara, A.R.; Longo, S. Bumblebees in natural and agro-ecosystems at different altitudes from Mount Etna, Sicily (Hymenoptera apidae bombinae): Long-term faunistic and ecological observations. Redia 2016, 98, $123-131$.

59. Vanderplanck, M.; Declèves, S.; Roger, N.; Decro, C.; Caulier, G.; Glauser, G.; Gerbaux, P.; Lognay, G.; Richel, A.; Escaravage, N.; et al. Is non-host pollen suitable for generalist bumblebees? Insect Sci. 2018, 25, 259-272. [CrossRef] [PubMed]

60. Hudon, T.M.; Plowright, C.M.S. Trapped: Assessing attractiveness of potential food sources to bumblebees. J. Insect Behav. 2011, 24, 144-158. [CrossRef]

61. Burger, H.; Dötterl, S.; Ayasse, M. Host-plant finding and recognition by visual and olfactory floral cues in an oligolectic bee. Funct. Ecol. 2010, 24, 1234-1240. [CrossRef]

62. Leonard, A.S.; Dornhaus, A.; Papaj, D.R. Flowers help bees cope with uncertainty: Signal detection and the function of floral complexity. J. Exp. Biol. 2011, 214, 113-121. [CrossRef] [PubMed]

63. Chittka, L.; Raine, N.E. Recognition of flowers by pollinators. Curr. Opin. Plant Biol. 2006, 9, 428-435. [CrossRef]

64. Vautard, R.; Honoré, C.; Beelmann, M.; Rouil, L. Simulation of ozone during the August 2003 heat wave and emission control scenarios. Atmos. Environ. 2005, 39, 2957-2967. [CrossRef]

65. Solberg, S.; Hov, O.; Sovde, A.; Isaksen, I.S.A.; Coddeville, P.; de Backer, H.; Forster, C.; Orsolini, Y.; Uhse, K. European surface ozone in the extreme summer 2003. J. Geophys. Res. 2008, 113, D07307. [CrossRef]

66. Roelofs, W.L. Electroantennogram assay: Rapid and convenient screening procedures for pheromones. In Techniques in Pheromone Research; Hummel, H.E., Miller, T.A., Eds.; Springer: New York, NY, USA, 1984; pp. 131-160.

67. Wright, G.A.; Lutmerding, A.; Dudareva, N.; Smith, B.H. Intensity and the ratios of compounds in the scent of snapdragon flowers affect scent discrimination by honey bees (Apis mellifera). J. Comp. Physiol. 2005, 191, 105-114. [CrossRef] [PubMed]

68. Suchet, C.; Dormont, L.; Schatz, B.; Giurfa, M.; Simon, V.; Raynaud, C.; Chave, J. Floral scent variation in two Antirrhinum majus subspecies influences the choice of naïve bumblebees. Behav. Ecol. Sociobiol. 2011, 65, 1015-1027. [CrossRef]

69. Fonta, C.; Masson, C. Comparative study by electrophysiology of olfactory responses in bumblebees (Bombus hypnorum and Bombus terrestris). J. Chem. Ecol. 1984, 10, 1157-1168. [CrossRef] [PubMed]

70. Laloi, D.; Sandoz, J.C.; Picard-Nizou, A.L.; Marchesi, A.; Povreau, A.; Taséi, J.N.; Poppy, G.; Pham-Delègue, M.H. Olfactory conditioning of the proboscis extension in bumble bees. Entomol. Exp. Appl. 1999, 90, 123-129. [CrossRef]

71. Anfora, G.; Rigosi, E.; Frasnelli, E.; Ruga, V.; Trona, F.; Vallortigara, G. Lateralization in the invertebrate brain: Left-right asymmetry of olfaction in bumble bee, Bombus terrestris. PLoS ONE 2011, 6, e18903. [CrossRef]

72. R Core Team. R: A Language and Environment for Statistical Computing. 2017. Available online: https://www.R-project.org/ (accessed on 21 April 2017).

73. Kuznetsova, A.; Brockhoff, P.B.; Christensen, R.H.B. lmerTest Package: Tests in linear mixed effects models. J. Stat. Softw. 2017, 82. [CrossRef]

74. Kuhn, M.; Weston, S.; Wing, J.; Forester, J.; Thaler, T. Contrast: A Collection of Contrast Methods. R Package Version 0.21. 2016. Available online: https:/ /CRAN.R-project.org/package=contrast (accessed on 31 March 2017).

75. Schad, D.J.; Vasishth, S.; Hohenstein, S.; Kliegl, R. How to capitalize on a priori contrasts in linear (mixed) models: A tutorial. J. Mem. Lang. 2020, 110, 104038. [CrossRef]

76. Hothorn, T.; Bretz, F.; Westfall, P. Simultaneous inference in general parametric models. Biom. J. 2008, 50, 346-363. [CrossRef]

77. Kelly, F.J.; Mudway, I.S. Protein oxidation at the air lung interface. Amino Acids 2003, 25, 375-396. [CrossRef]

78. Leal, W.S. Odorant reception in insects: Roles of receptors, binding proteins, and degrading enzymes. Annu. Rev. Entomol. 2013, 58, 373-391. [CrossRef]

79. Kadala, A.; Charreton, M.; Jakob, I.; Le Conte, Y.; Collet, C. A use-dependent sodium current modification induced by type I pyrethroid insecticides in honeybee antennal olfactory receptor neurons. Neurotoxicology 2011, 32, 320-330. [CrossRef] [PubMed]

80. Felton, G.W.; Summers, C.B. Antioxidant systems in insects. Arch. Insect Biochem. Physiol. 1995, 29, 187-197. [CrossRef] [PubMed]

81. Perić-Mataruga, V.; Nenadović, V.; Ivanović, J. Neurohormones in insect stress: A review. Arch. Biol. Sci. 2006, 58, 1-12. [CrossRef]

82. Krishnan, N.; Kodrík, D. Endocrine control of oxidative stress in insects. In Oxidative Stress in Vertebrates and Invertebrates: Molecular Aspects of Cell Signaling; Farooqui, T., Farooqui, A.A., Eds.; Wiley-Blackwell: Hoboken, NJ, USA, 2012 ; pp. $261-270$.

83. Vandenberg, L.N.; Colborn, T.; Hayes, T.B.; Heindel, J.J.; Jacobs, D.R.; Lee, D.-H.; Shioda, T.; Soto, A.M.; vom Saal, F.S.; Welshons, W.V.; et al. Hormones and endocrine-disrupting chemicals: Low-dose effects and nonmonotonic dose responses. Endocr. Rev. 2012, 33, 378-455. [CrossRef]

84. Kodrik, D.; Bednarova, A.; Zemanova, M.; Krishnan, N. Hormonal regulation of response to oxidative stress in insects-An Update. Int. J. Mol. Sci. 2015, 16, 25788-25816. [CrossRef]

85. Bonvehí, J.S.; Torrentó, M.S.; Lorente, E.C. Evaluation of polyphenolic and flavonoid compounds in honeybee-collected pollen produced in Spain. J. Agric. Food Chem. 2001, 49, 1848-1853. [CrossRef]

86. Johnson, K.S.; Felton, G.W. Plant phenolics as dietary antioxidants for herbivorous insects: A test with genetically modified tobacco. J. Chem. Ecol. 2001, 27, 2579-2597. [CrossRef] 
87. Monaghan, P.; Metcalfe, N.B.; Torres, R. Oxidative stress as a mediator of life history trade-offs: Mechanisms, measurements and interpretation. Ecol. Lett. 2009, 12, 75-92. [CrossRef]

88. Beaulieu, M.; Schaefer, H.M. Rethinking the role of dietary antioxidants through the lens of self-medication. Anim. Behav. 2013, 86, 17-24. [CrossRef] 